\title{
Distribution of Heavy Metals in Lake Muhazi, Rwanda
}

\author{
Innocent Nhapi ${ }^{\mathrm{a}}$, Umaru Garba Wali ${ }^{\mathrm{b}}$, , Denise Usanzineza ${ }^{\mathrm{b}}$, Japhet J. Kashaigili ${ }^{\mathrm{c}}$, Noble Banadda ${ }^{\mathrm{d}}$ \\ and Richard Kimwaga ${ }^{e}$
}

\author{
${ }^{a}$ Department of Civil Engineering, University of Zimbabwe, Box MP167, Mt. Pleasant, Harare, Zimbabwe \\ ${ }^{b}$ WREM Program, Department of Civil Engineering, Faculty of Applied Science, National University of Rwanda, \\ Box 117 Butare, Rwanda \\ ${ }^{c}$ Faculty of Forestry and Nature Conservation, Sokoine University of Agriculture, Box 3003 Morogoro, Tanzania \\ ${ }^{d}$ Department of Agricultural and Bio Systems Engineering, Makerere University, P.O. Box 7062, Kampala, Uganda \\ ${ }^{e}$ Department of Water Resources Engineering, University of Dar es Salaam P. O. Box 35131, Dar es Salaam, Tanzania
}

\begin{abstract}
The pollution of lakes is mainly conceived in terms of nutrient levels and eutrophication with the consequent development of algal blooms and fish kills. However, heavy metals are increasingly becoming prominent especially for water bodies closer to urban and mining areas. This study focuses on heavy metal pollution in lakes using a case study of Lake Muhazi in Rwanda. The study characterized the horizontal and vertical distribution of heavy metals in the Lake, with the research conducted from July to October 2007. The parameters studied are cadmium, chromium, copper, iron, lead, manganese, zinc, $\mathrm{pH}$ and temperature. The samples were collected at different depths in the Lake using a Van Dorn Bottle water sampler, and were analyzed using standard methods. The temperature and $\mathrm{pH}$ were measured in the field using $\mathrm{HACH}$ field testing kits. The findings indicated that the mean concentration of $\mathrm{Zn}$ was $0.041 \pm 0.045 \mathrm{mg} / \mathrm{L}, \mathrm{Cd}$ $0.026 \pm 0.029 \mathrm{mg} / \mathrm{L}, \mathrm{Pb} 0.292 \pm 0.442 \mathrm{mg} / \mathrm{L}, \mathrm{Fe} 0.756 \pm 0.734 \mathrm{mg} / \mathrm{L}$, and $\mathrm{Mn} 0.340 \pm 0.336 \mathrm{mg} / \mathrm{L}$. Chromium and copper were not detected in the water samples. The findings indicate that the concentrations of Cadmium, Iron and Lead far exceeded the recommended levels for aquatic life at all sampling points. The high levels of heavy metals are attributed to the riparian landuse practices such as uncontrolled agriculture, urban runoff and mining activities around the Lake. It is recommended that a detailed study of the catchment be carried out to identify and isolate the main sources of heavy metals in the Lake so that appropriate control measures could be developed.
\end{abstract}

Keywords: Heavy metals, lake water quality, lake Muhazi, pollution, Rwanda, water quality management.

\section{INTRODUCTION}

Some heavy metals are essential for life processes. Heavy metals such as $\mathrm{Cu}, \mathrm{Fe}, \mathrm{Mn}, \mathrm{Ni}$ and $\mathrm{Zn}$ are important in plants and micro organisms as micronutrients. Others known as trace metals are naturally found in the body at low concentrations and are essential for human health. Iron, for example, prevents anaemia, and zinc is a cofactor in over 100 enzyme reactions. However, some heavy metals such as $\mathrm{Cd}$, $\mathrm{Cr}$, and $\mathrm{Pb}$ have no known physiological activity, but they have proved detrimental beyond a certain limit. Diseases like edema of eyelids, tumor, congestion of nasal mucous membrane and pharynx, stuffiness of head, gastrointestinal, muscular, reproductive, neurological and genetic malfunctions are caused by some of these heavy metals [1]. Heavy metals have therefore received considerable public attention from

*Address correspondence to this author at the WREM Program, Department of Civil Engineering, Faculty of Applied Science, National University of Rwanda, Box 117 Butare, Rwanda; Tel. +250788877174;

E-mail: ugarbawali@nur.ac.rw,ugwas@yahoo.com all over the world because of the concern that they will cause long-term damage to the environment [2]. The toxicity of a metal is usually defined in terms of the concentration required to cause an acute response (usually death) or a sublethal response [3]. The risk of adverse effects is greatest during long-term exposure, but acute effects could occur when the concentrations rise above 3-10 times as high as the lowest harmful level.

According to Panda et al. [4], the primary sources of heavy metals pollution in lakes are the input from rivers, sediments and the atmosphere. On the other hand Ljung [5] gives a variety of pathways for heavy metals pollution. These include both natural and anthropogenic sources such as atmospheric deposition, weathering of rocks, erosion, runoff, untreated sewage, agricultural activities, industries and mining, etc. Although some kind of water pollution could occur through natural processes, pollution is mostly a result of human activities [4]. The occurrence of heavy metal contaminants in excess of natural loads has become a problem of increasing concern. This situation has arisen as a result of the rapid population growth, increased urbanization, 


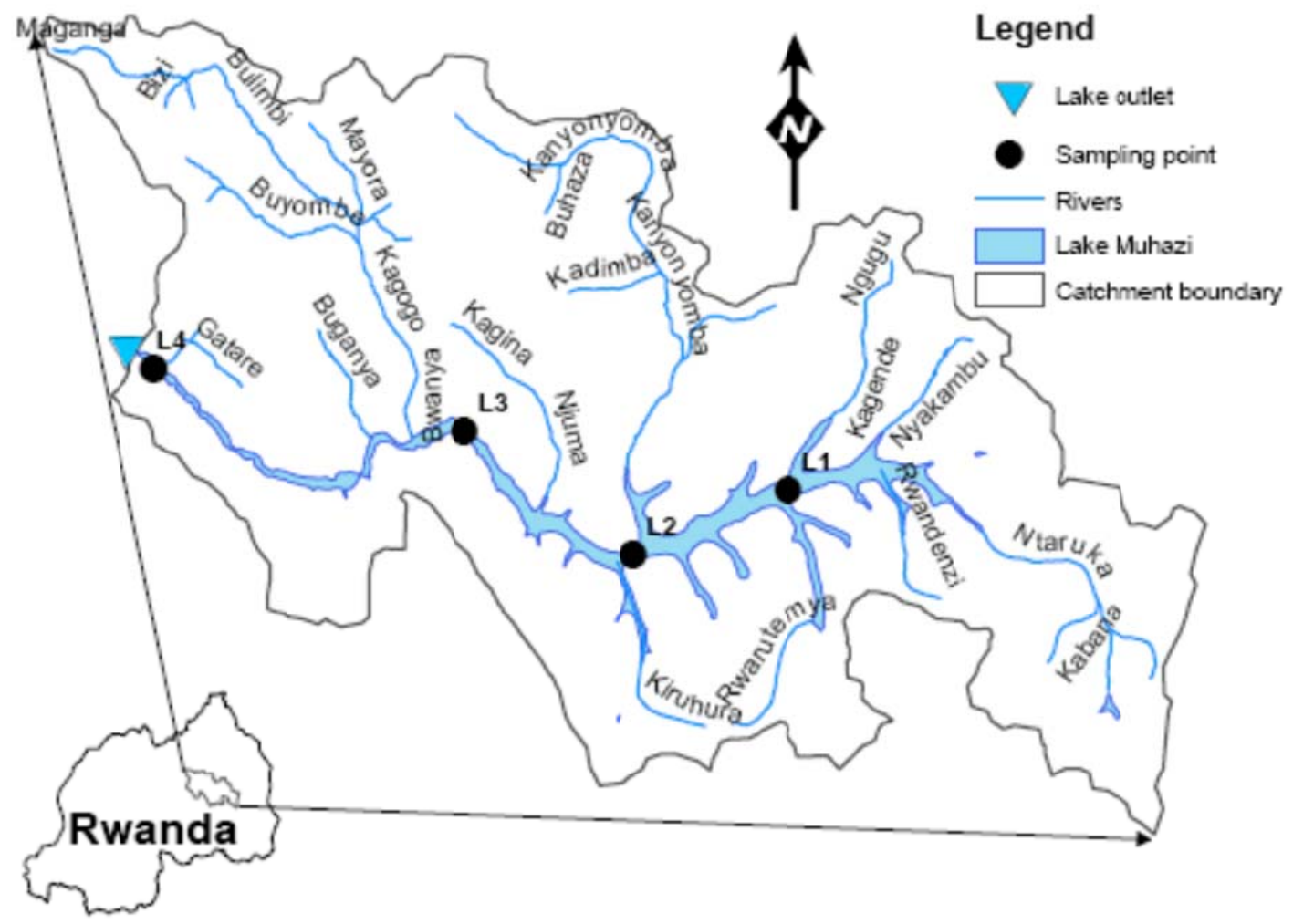

Fig. (1). Map of the Lake Muhazi Catchment showing the location of sampling sites inside Lake Muhazi for points monitored July-Sept'07 (L1:Kavumu, L2:Nyarubuye, L3:Kibilizi and L3:Rwesero).

and expansion of industrial activities, exploration and exploitation of natural resources, extension of irrigation and other modern agricultural practices as well as the lack of environmental regulations or its enforcement [6]. According to UNEP [7], Lake Nakuru and Lake Bogoria in Kenya experienced a large number of deaths among the flamingos for which the lakes are famous in 2001. Pollution by heavy metals is suspected to be the primary cause of these deaths, resulting from the contamination of the lakes by sewage, industrial effluent and organochlorines, which were present in agricultural runoff.

Heavy metal pollution has also been detected in large lakes. According to FAO [6], earlier studies on sediment, water and biota in the Lake Victoria (the second largest natural lake in the world) showed no significant heavy metal pollution. However, other studies revealed increased Lead levels largely due to increased shipping traffic and associated problems, car washing and discharge from local industries [8, 9]. Ochumba [10] studied physico-chemical parameters, dissolved oxygen and heavy metal concentrations in Lake Victoria as the possible causes of periodic fish kills and he attributed the fish kills to dissolved oxygen depletion. Ljung [5] found that the concentrations of $\mathrm{Ni}$ and $\mathrm{Cr}$ were satisfactory regarding environmental quality at all sites investigated in Uganda. At most sites, the concentrations of $\mathrm{Cd}, \mathrm{Cu}, \mathrm{Pb}$ and $\mathrm{Zn}$ were too high to ensure environmental stability with a special concern about $\mathrm{Pb}$ and $\mathrm{Cd}$. Kisamo [11] found that the concentration of lead in Lake Victoria waters ranged from $0.35 \mathrm{ppm}$ to $0.63 \mathrm{ppm}$ for copper, while the chromium and cadmium concentrations at all sites sampled on the Tan- zanian side ranged up to $0.01 \mathrm{ppm}$. The zinc concentration in waters ranged from $0.04 \mathrm{ppm}$ to $0.08 \mathrm{ppm}$ and that of iron from $0.01 \mathrm{ppm}$ to $5.62 \mathrm{ppm}$.

This work uses a case study of Lake Muhazi in Rwanda to understand the distribution of heavy metal pollution in the lakes. Lake Muhazi is one of the important surface water bodies in Rwanda located in the central-eastern part of the country. The lake is the main source of water for domestic and agricultural activities in the area. Lake Muhazi is a natural lake which is characterized by both urban and rural pollution, mainly from poorly managed rural farming practices. The lake shores are now being developed for ecotourism and semi-intensive agricultural activities. The water quality of the lake is threatened by increased heavy metal loading from different sources but most notably from the tributary rivers. There is a dearth of information to describe the concentration of heavy metals in the Lake, although it is quite obvious that the presence of heavy metals generally reported in the area $[12,13]$, would result in the metals accumulating in the lake overtime. The research results would enhance understanding of the heavy metal pollution and enable informed decisionmaking on the management of the lake and its environs; including other lakes under similar conditions.

\section{MATERIALS AND METHODS}

\section{Description of the Study Area}

Lake Muhazi is one of the natural lakes in Rwanda and is located about $20 \mathrm{~km}$ on the eastern side of the capital city of Kigali (Fig. 1). The lake is in a mountainous area where the 
main activities are rice cultivation in valley bottoms, ecotourism, some mining around the lake and part of the nearby town of Rwamagana. The catchment area is estimated to be $830 \mathrm{~km}^{2}$ and the lake itself covers an area of about $34.1 \mathrm{~km}^{2}$ and a volume of about $330 \times 10^{6} \mathrm{~m}^{3}$ [14]. The Rwamagana District developed a master plan which mainly focuses on proposed activities in and around the lake. Currently, the lake is surrounded by tourist activities (such as boat clubs, hotels, high value residential buildings, etc) and some institutional establishments such as schools, churches and training camps. The envisaged master plan, with a time horizon of 30 to 50 years, will see extensive and high-value developments around the lake, with potential impacts on water quality.

\section{Sample Collection and Analysis}

Samples were collected at four sites located along the length of the lake (Fig. 1) from July to October 2007. The samples were collected using a Van Dorn sampling bottle and stored in $560 \mathrm{ml}$ plastic bottles which were thoroughly washed and left to stand in $1 \mathrm{M} \mathrm{HCl}$ overnight and were rinsed twice in the field with sample water before final collection. The samples were stored on ice in cooler boxes and transported to the laboratory. The temperature and the $\mathrm{pH}$ were measured in the field using portable $\mathrm{HACH}$ meters. A GPS was used to mark and identify the sampling sites. At each site in the lake, water samples were collected at depths of $0.5 \mathrm{~m}, 2 \mathrm{~m}$, and $5 \mathrm{~m}$. The last sample collected was $1 \mathrm{~m}$ from the bottom of the lake.

The total metal samples $(\mathrm{Cd}, \mathrm{Cr}, \mathrm{Cu}, \mathrm{Fe}, \mathrm{Mn}, \mathrm{Pb}$, and $\mathrm{Zn}$ ) were digested with nitric acid. The concentrations of total metals were then determined using a Perkin-Elmer Atomic Absorption Spectrophotometer. The detection limit of heavy metals using this machine is $0.001 \mathrm{mg} / \mathrm{L}$ and results in this paper are conveniently reported to 3 decimal places.

\section{Data Analysis}

A total of 41 samples were collected and analyzed from the lake. The descriptive statistics of the results are presented in terms of means, ranges and standard deviations. As well as the results for each parameter at each sampling points for all the depths and samplings were presented. The data were tested for variability within and between the groups using ANOVA.

\section{RESULTS}

\section{Heavy Metal Levels in Lake Muhazi}

Five metals were detected in the water samples of Lake Muhazi at varying concentrations. These were cadmium, iron, manganese, lead and zinc. Chromium and Copper were practically not detected at all sampling sites in the Lake. The absence of Copper is similar to the findings by Nzeyimana [13] and Nshimiyimana [15] who did not detect significant levels of copper in surface and ground water samples.

The concentration of $\mathrm{Zn}$ in the water column was between 0.007 and $0.225 \mathrm{mg} / \mathrm{L}$, for $\mathrm{Cd} ; 0.001 \mathrm{mg} / \mathrm{L}$ and 0.091 $\mathrm{mg} / \mathrm{L}$, for $\mathrm{Pb} ; 0.008$ and $1.540 \mathrm{mg} / \mathrm{L}$ for $\mathrm{Mn} ; 0.068$ and 1.738 $\mathrm{mg} / \mathrm{L}$, for $\mathrm{Fe} ; 0.132$ and $4.591 \mathrm{mg} / \mathrm{L}$, and for $\mathrm{Cr} ; 0$ and 0.002 $\mathrm{mg} / \mathrm{L}$ (Table 1).
Table 1. The concentrations of heavy metals $(\mathrm{mg} / \mathrm{L})$ in Lake Muhazi, July to Oct'07

\begin{tabular}{|c|c|c|c|c|}
\hline Metal & N & Range & Mean & Std. Deviation \\
\hline \hline Zinc & 41 & 0.218 & 0.041 & 0.045 \\
\hline Cadmium & 41 & 0.09 & 0.026 & 0.029 \\
\hline Lead & 41 & 1.532 & 0.292 & 0.442 \\
\hline Iron & 41 & 4.459 & 0.756 & 0.734 \\
\hline Manganese & 41 & 1.67 & 0.34 & 0.336 \\
\hline
\end{tabular}

Table 2. The Vertical Distribution of Heavy Metals (mg/L) in Lake Muhazi at Site L1, July to Oct'07

\begin{tabular}{|c|c|c|c|c|c|}
\hline Depths & Cadmium & Lead & Zinc & Iron & Manganese \\
\hline \hline 1st sampling \\
\hline $0.5 \mathrm{~m}$ & 0.064 & 0.870 & 0.068 & 0.870 & 0.145 \\
\hline $2 \mathrm{~m}$ & 0.074 & 1.021 & 0.057 & 1.373 & 0.143 \\
\hline $5 \mathrm{~m}$ & 0.075 & 1.101 & 0.047 & 0.633 & 0.146 \\
\hline $11 \mathrm{~m}$ & 0.086 & 1.123 & 0.225 & 1.325 & 0.510 \\
\hline 2nd sampling & \multicolumn{5}{|l}{} \\
\hline $0.5 \mathrm{~m}$ & 0.009 & 0.038 & 0.014 & 0.134 & 0.071 \\
\hline $2 \mathrm{~m}$ & 0.013 & 0.053 & 0.014 & 0.132 & 0.076 \\
\hline $5 \mathrm{~m}$ & 0.009 & 0.039 & 0.018 & 0.313 & 0.108 \\
\hline $11 \mathrm{~m}$ & 0.008 & 0.070 & 0.018 & 0.394 & 0.339 \\
\hline 3rd sampling & \multicolumn{5}{|l}{} \\
\hline $0.5 \mathrm{~m}$ & 0.016 & 0.054 & 0.026 & 0.231 & 0.068 \\
\hline $2 \mathrm{~m}$ & 0.004 & 0.065 & 0.043 & 0.486 & 0.081 \\
\hline $5 \mathrm{~m}$ & 0.005 & 0.046 & 0.025 & 0.604 & 0.106 \\
\hline $11 \mathrm{~m}$ & 0.007 & 0.045 & 0.062 & 0.538 & 0.275 \\
\hline
\end{tabular}

Table 3. The Vertical Distribution of Heavy Metals (mg/L) in Lake Muhazi at Site L2, July to Oct'07

\begin{tabular}{|c|c|c|c|c|c|}
\hline Depths & Cadmium & Lead & Zinc & Iron & Manganese \\
\hline \hline 1st sampling \\
\hline $0.5 \mathrm{~m}$ & 0.084 & 0.789 & 0.108 & 4.591 & 0.569 \\
\hline $2 \mathrm{~m}$ & 0.084 & 0.696 & 0.078 & 1.208 & 0.212 \\
\hline $5 \mathrm{~m}$ & 0.087 & 0.704 & 0.053 & 0.952 & 0.328 \\
\hline $12 \mathrm{~m}$ & 0.091 & 0.661 & 0.078 & 1.095 & 0.327 \\
\hline 2nd sampling & \multicolumn{5}{|l|}{} \\
\hline $0.5 \mathrm{~m}$ & 0.011 & 0.018 & 0.010 & 0.560 & 0.089 \\
\hline $2 \mathrm{~m}$ & 0.013 & 0.026 & 0.012 & 0.258 & 0.134 \\
\hline $5 \mathrm{~m}$ & 0.009 & 0.044 & 0.013 & 0.214 & 0.118 \\
\hline $12 \mathrm{~m}$ & 0.011 & 0.036 & 0.013 & 0.165 & 0.726 \\
\hline 3rd sampling & & & \\
\hline $0.5 \mathrm{~m}$ & 0.011 & 0.063 & 0.055 & 0.482 & 0.115 \\
\hline $2 \mathrm{~m}$ & 0.013 & 0.076 & 0.034 & 0.834 & 0.105 \\
\hline $5 \mathrm{~m}$ & 0.011 & 0.008 & 0.054 & 0.532 & 0.116 \\
\hline $12 \mathrm{~m}$ & 0.009 & 0.089 & 0.105 & 0.820 & 0.491 \\
\hline
\end{tabular}

Tables $\mathbf{2}, \mathbf{3}$ and $\mathbf{4}$ show the variation of heavy metals in Lake Muhazi. Metal concentrations seemed to be high at the one metre level from the bottom at almost all sites. 
Table 4. The Vertical Distribution of Heavy Metals $(\mathrm{mg} / \mathrm{L})$ in Lake Muhazi at site L3, July to Oct'07

\begin{tabular}{|c|c|c|c|c|c|}
\hline Depths & Cadmium & Lead & Zinc & Iron & Manganese \\
\hline \hline 1st sampling \\
\hline $0.5 \mathrm{~m}$ & 0.037 & 1.525 & 0.176 & 1.712 & 0.618 \\
\hline $2 \mathrm{~m}$ & 0.029 & 0.074 & 0.019 & 0.937 & 0.765 \\
\hline $5 \mathrm{~m}$ & 0.026 & 0.102 & 0.018 & 0.524 & 0.463 \\
\hline $10 \mathrm{~m}$ & 0.056 & 0.154 & 0.020 & 0.964 & 1.738 \\
\hline 2nd sampling & \multicolumn{5}{|l}{} \\
\hline $0.5 \mathrm{~m}$ & 0.005 & 0.047 & 0.009 & 0.205 & 0.143 \\
\hline $2 \mathrm{~m}$ & 0.011 & 0.015 & 0.016 & 0.327 & 0.199 \\
\hline $5 \mathrm{~m}$ & 0.007 & 0.041 & 0.013 & 0.436 & 0.468 \\
\hline $10 \mathrm{~m}$ & 0.008 & 0.016 & 0.015 & 0.536 & 0.699 \\
\hline 3rd sampling & & & \\
\hline $0.5 \mathrm{~m}$ & 0.007 & 0.031 & 0.024 & 1.315 & 0.109 \\
\hline $2 \mathrm{~m}$ & 0.002 & 0.019 & 0.037 & 1.141 & 0.132 \\
\hline $5 \mathrm{~m}$ & 0.008 & 0.136 & 0.014 & 0.731 & 0.547 \\
\hline $10 \mathrm{~m}$ & 0.008 & 0.045 & 0.021 & 1.328 & 1.021 \\
\hline
\end{tabular}

Fig. (2) shows the horizontal distribution of heavy metals in Lake Muhazi. The mean concentration of $\mathrm{Pb}$ in Lake Muhazi peaked at $\mathrm{L} 1(0.417 \mathrm{mg} / \mathrm{L})$ and decreased towards the western side of the lake with a slight increase at L3 $(0.322 \mathrm{mg} / \mathrm{L})$. The lowest mean concentration of $\mathrm{Pb}$ is observed at $\mathrm{L} 4(0.037 \mathrm{mg} / \mathrm{L})$. The highest mean concentration of $\mathrm{Fe}$ is observed at $\mathrm{L} 2(0.976 \mathrm{mg} / \mathrm{L})$ and the lowest at L4 $(0.421 \mathrm{mg} / \mathrm{L})$. The mean concentration of $\mathrm{Mn}$ in Lake Muhazi increased towards the outlet of the lake with a peak at $\mathrm{L} 3(0.575 \mathrm{mg} / \mathrm{L})$ and the lowest mean concentration at $\mathrm{L} 1$ $(0.172 \mathrm{mg} / \mathrm{L})$. The mean concentration of $\mathrm{Zn}$ in Lake Muhazi decreased towards the outlet of the lake. The mean concentrations of $\mathrm{Zn}$ were equal to $0.051 \mathrm{mg} / \mathrm{L}$ at $\mathrm{L} 1$ and $\mathrm{L} 2$ and decreased to $0.032 \mathrm{mg} / \mathrm{L}$ at $\mathrm{L} 3$ and to $0.011 \mathrm{mg} / \mathrm{L}$ at $\mathrm{L} 4$ (Table 5).

\section{DISCUSSION}

\section{Heavy Metal Levels in Lake Muhazi}

Generally the profiles of each heavy metal show high concentrations of heavy metals at the $1 \mathrm{~m}$ depth from the bottom of the lake except for Fe whose highest concentration was at the surface $(0.5 \mathrm{~m})$. High values of heavy metals, except $\mathrm{Cd}$, were found at $0.5 \mathrm{~m}$ depth at sites $\mathrm{L} 2$ and $\mathrm{L} 3$. The high concentrations at the surface are attributed to pollution due to lake navigation by motor boats and geologic sources. The high concentration of heavy metals in the water column at $1 \mathrm{~m}$ depth from the bottom of the lake as shown on Tables $\mathbf{2}, \mathbf{3}$ and $\mathbf{4}$ is explained by the fact that the lake sediments are a major repository of heavy metals, which could be released to overlying water column from the sediments when environmental conditions change [16]. The L3 site shows high concentration of heavy metals such as $\mathrm{Mn}$ and $\mathrm{Fe}$. This is not unusual as most parts of Rwanda report high values of $\mathrm{Mn}$ and $\mathrm{Fe}$ due to geologic formations [13]. The concentration of $\mathrm{Zn}$ and that of Cd peaked at L2 site, showing that there is some input of this pollution near this point. The point is located near a disused mine and it is suspected that the pollution is originating from this source. However, further studies are required to really pinpoint the sources. The concentration of $\mathrm{Pb}$ was found to be higher at L1 site largely due to contamination of the site by motor boats in the lake.
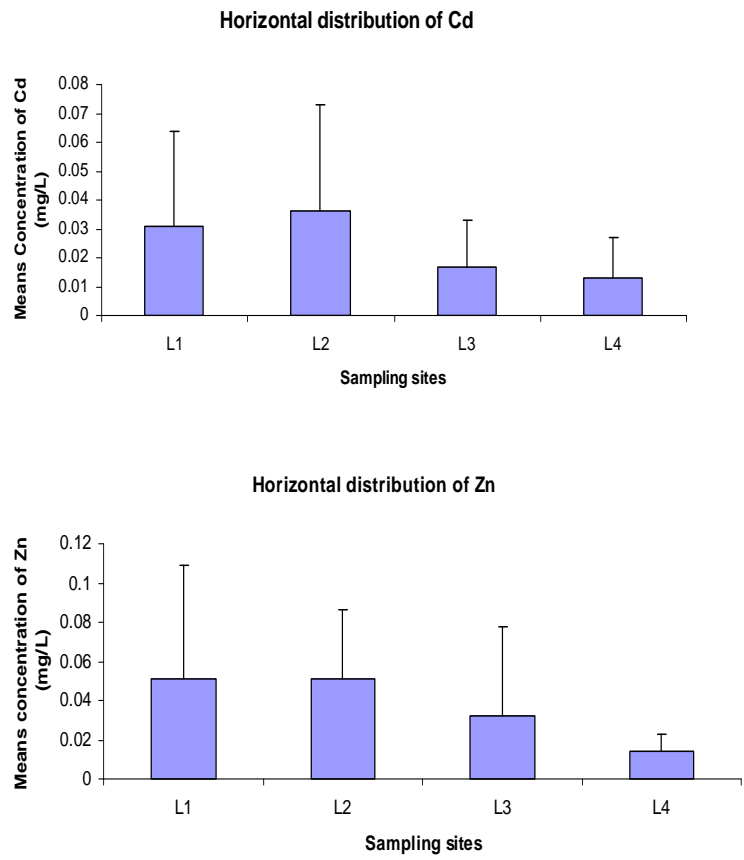

Horizontal distribution of $\mathrm{Pb}$

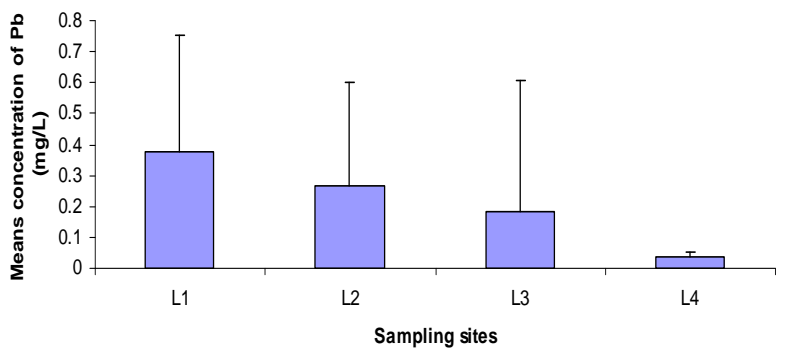

Horizontal distribution of $\mathrm{Fe}$

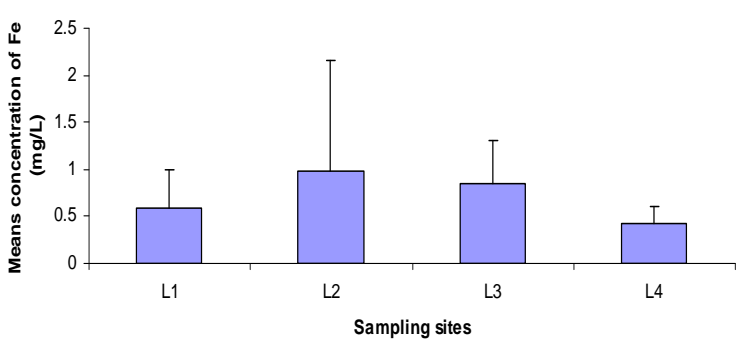

Fig. (2). Mean Concentrations of $\mathrm{Cd}, \mathrm{Pb}, \mathrm{Zn}, \mathrm{Fe}$ and $\mathrm{Mn}$ in Lake Muhazi, July to Oct'07. 
Table 5. The Horizontal Distribution of Heavy Metals $(\mathrm{mg} / \mathrm{L})$ in Lake Muhazi, July to Oct'07

\begin{tabular}{|c|c|c|c|c|c|}
\hline Sites & Cadmium & Lead & Zinc & Iron & Manganese \\
\hline \hline L1 & $0.031 \pm 0.033$ & $0.377 \pm 0.037$ & $0.051 \pm 0.058$ & $0.586 \pm 0.417$ & $0.172 \pm 0.136$ \\
\hline L2 & $0.036 \pm 0.037$ & $0.268 \pm 0.331$ & $0.051 \pm 0.035$ & $0.976 \pm 1.189$ & $0.278 \pm 0.214$ \\
\hline L3 & $0.017 \pm 0.016$ & $0.184 \pm 0.425$ & $0.032 \pm 0.046$ & $0.846 \pm 0.464$ & $0.575 \pm 0.464$ \\
\hline L4 & $0.013 \pm 0.014$ & $0.034 \pm 0.016$ & $0.014 \pm 0.009$ & $0.42 \pm 0.180$ & $0.175 \pm 0.11$ \\
\hline
\end{tabular}

Table 6. Comparison of Mean of Measured Metals with WHO Standard Guidelines

\begin{tabular}{|c|c|c|c|c|c|c|}
\hline \multirow{2}{*}{ Metal } & \multicolumn{4}{|c|}{ Mean of Measured Metal } & Aquatic Life Limit [17] & WHO Guideline [18] \\
\cline { 2 - 7 } & $\mathbf{L 1}$ & $\mathbf{L 2}$ & $\mathbf{L 3}$ & $\mathbf{L 4}$ & Life in the Lake & Drinking Water \\
\hline \hline $\mathrm{Cd}(\mathrm{mg} / \mathrm{L})$ & 0.031 & 0.036 & 0.017 & 0.013 & $1.7 \times 10^{-5}$ & 0.003 \\
\hline $\mathrm{Fe}(\mathrm{mg} / \mathrm{L})$ & 0.586 & 0.976 & 0.846 & 0.42 & 0.3 & Not defined but $2 \mathrm{mg} / \mathrm{L}$ may be acceptable to consumers \\
\hline $\mathrm{Pb}(\mathrm{mg} / \mathrm{L})$ & 0.377 & 0.268 & 0.184 & 0.034 & $0.001-0.007$ & 0.01 \\
\hline $\mathrm{Mn}(\mathrm{mg} / \mathrm{L})$ & 0.172 & 0.276 & 0.575 & 0.175 & Not defined & 0.4 \\
\hline $\mathrm{Zn}(\mathrm{mg} / \mathrm{L})$ & 0.051 & 0.051 & 0.032 & 0.014 & 0.03 & Not defined but 3 mg/L may not be acceptable to consumers \\
\hline
\end{tabular}

Table 7. ANOVA of Heavy Metals Distribution in the Lake Muhazi for Four Sites Monitored July to Oct'07

\begin{tabular}{|c|c|c|c|c|c|c|}
\hline & & Sum of Squares & df & Mean Square & $\mathbf{F}$ & Sig. \\
\hline \multirow[t]{3}{*}{$\mathrm{Pb}$} & Between Groups & 0.515 & 3 & 0.172 & \multirow[t]{3}{*}{0.868} & \multirow[t]{3}{*}{0.466} \\
\hline & Within Groups & 7.313 & 37 & \multirow[t]{2}{*}{0.198} & & \\
\hline & Total & 7.828 & 40 & & & \\
\hline \multirow[t]{3}{*}{$\mathrm{Zn}$} & Between Groups & 0.007 & 3 & 0.002 & \multirow[t]{3}{*}{1.126} & \multirow[t]{3}{*}{0.351} \\
\hline & Within Groups & 0.075 & 37 & \multirow[t]{2}{*}{0.002} & & \\
\hline & Total & 0.081 & 40 & & & \\
\hline \multirow[t]{3}{*}{$\mathrm{Cd}$} & Between Groups & 0.003 & 3 & 0.001 & \multirow[t]{3}{*}{1.327} & \multirow[t]{3}{*}{0.280} \\
\hline & Within Groups & 0.031 & 37 & \multirow[t]{2}{*}{0.001} & & \\
\hline & Total & 0.034 & 40 & & & \\
\hline \multirow[t]{3}{*}{$\mathrm{Fe}$} & Between Groups & 1.589 & 3 & 0.530 & \multirow[t]{3}{*}{0.982} & \multirow[t]{3}{*}{0.412} \\
\hline & Within Groups & 19.960 & 37 & \multirow[t]{2}{*}{0.539} & & \\
\hline & Total & 21.550 & 40 & & & \\
\hline \multirow[t]{3}{*}{$\mathrm{Mn}$} & Between Groups & 1.048 & 3 & 0.349 & \multirow[t]{3}{*}{3.729} & \multirow[t]{3}{*}{0.019} \\
\hline & Within Groups & 3.467 & 37 & \multirow[t]{2}{*}{0.094} & & \\
\hline & Total & 4.516 & 40 & & & \\
\hline
\end{tabular}

\section{Comparison of Measured Metals with Guideline Values}

Mean values for each indicator at each site in Lake Muhazi were compared with guideline values as shown in Table 6.

In some cases, the water is not suitable for aquatic life and this could explain why there are very few fish in the lake. In comparing analysis results of the water column at the four sites in Lake Muhazi with WHO Drinking Water Quality Guidelines, the following observations were made:

- Cadmium: WHO drinking water quality guidelines were exceeded at all sites.

- Iron: WHO drinking water quality guidelines were not exceeded at all sites.
- Lead: WHO drinking water quality guidelines were exceeded at all sites.

- Manganese: WHO drinking water quality guideline value was exceeded at L3 only.

- Zinc: No exceedences from WHO drinking water quality guideline were observed at any site.

ANOVA tests were conducted to determine the variability of the concentration of the measured parameters within and between the sampling points. The results of the ANOVA tests for $\mathrm{Pb}, \mathrm{Zn}, \mathrm{Cd}, \mathrm{Fe}$ and $\mathrm{Mn}$ are presented in Table 7. These results can be further summarized as follows: $\mathrm{Pb}(\mathrm{F}(3,37)=0.868, \mathrm{P}=0.466), \mathrm{Zn}(\mathrm{F}(37,40)=1.126, \mathrm{P}=0.351)$, $\mathrm{Cd}(\mathrm{F}(3,37)=1.327, \mathrm{P}=0.280), \mathrm{Fe}(\mathrm{F}(3,37)=0.982, \mathrm{P}=0.412)$, and $\operatorname{Mn}(\mathrm{F}(37,407)=3.729, \mathrm{P}=0.019)$. As seen for all the pa- 
rameters with the exception of $\mathrm{Pb}$ the $\mathrm{p}$-value is greater than 0.05 . This means that, with the exception of $\mathrm{Pb}$, the difference in the concentrations of the measured parameters are not statistically significant both within and between the sampling points.

\section{CONCLUSIONS AND RECOMMENDATIONS}

The results of heavy metals distribution in Lake Muhazi are presented. In general with the exception of Lead for all there were no statistically significant differences between (at the same sampling point vertically with time) and within (at different sampling points horizontally with time) the groups. The means and standard deviations at each sampling points for all the parameters are presented. It should be noted that Lake Muhazi is the main source of domestic water supply for the riparian communities some with and others without treatment. The value of the parameters was compared with the WHO guidelines for drinking water the result show that Cadmium, Iron and Lead exceeded the standard values for all sites and depths, while manganese exceeded only at L3 sampling point.

From the results and discussions in this paper, the following recommendations were derived:

1. There is a need for identifying all controllable sources of pollution (e.g., agricultural sources; domestic sewage disposal practices) throughout the watershed of Lake Muhazi to enable the development of appropriate preventive measures.

2. There is a need for the control of the major pollution sources such as the motorway, wastewater intrusions, washing and bathing in the lake, disused mines, and Inflow Rivers of the lake.

3. More concerted long-term monitoring is required at least for a year to cover seasonality. This would give a complete picture of the pollution status of the lake.

4. There is a need for carrying out a research on the Lake sediment as it is presently suspected that heavy metals could be reloading from sediments.

5. Due mainly to limited financial resources, we did not cover mercury in our study, which we believe is an essential parameter in such studies. We therefore strongly recommend that future studies on heavy metal pollution in Lake Muhazi should include mercury.

\section{CONFLICT OF INTEREST}

None declared.

\section{ACKNOWLEDGEMENTS}

The authors are very grateful to Inter-University Council of Eastern Africa through Lake Victoria Research (VicRes) for accepting to pay for the publication of this work. We also thank Nuffic for sponsoring this study through the WREM Project, a collaborative capacity building project between the National University of Rwanda and the UNESCO-IHE Institute for Water Education.

\section{NOMENCLATURE}

$\begin{array}{lll} \pm & = & \text { plus or minus } \\ \% & = & \text { Percentage } \\ \mathrm{Cd} & = & \text { Cadmium } \\ \mathrm{Cr} & = & \text { Chromium } \\ \mathrm{Cu} & = & \text { Copper } \\ \mathrm{Fe} & = & \text { Iron } \\ \mathrm{km} & & \\ \mathrm{M} & = & \text { mole } \\ \mathrm{mg} / \mathrm{L} & = & \text { milligram per liter } \\ \mathrm{Mn} & = & \text { Manganese } \\ \mathrm{Ni} & = & \text { Nickel } \\ \mathrm{Pb} & = & \text { Lead } \\ \mathrm{ppm} & = & \text { part per million } \\ \mathrm{Zn} & = & \text { Zink }\end{array}$

\section{ACRONYMS}

\begin{tabular}{|c|c|c|}
\hline ANOVA & $=$ & Analysis of variance \\
\hline FAO & $=$ & $\begin{array}{l}\text { Food and Agricultural organiza- } \\
\text { tion of the united nations }\end{array}$ \\
\hline GPS & $=$ & Global Positioning System \\
\hline $\mathrm{HCl}$ & $=$ & Hydrochloric Acid \\
\hline $\mathrm{pH}$ & $=$ & Potential Hydrogen \\
\hline UNEP & $=$ & $\begin{array}{l}\text { United Nation Environmental } \\
\text { Protection }\end{array}$ \\
\hline UNESCO-IHE & $=$ & $\begin{array}{l}\text { UNESCO Institute of Water Edu- } \\
\text { cation }\end{array}$ \\
\hline VICRES & $=$ & Lake Victoria Research Initiative \\
\hline WHO & $=$ & World Health Organization \\
\hline WREM & $=$ & $\begin{array}{l}\text { Water Resources and Environ- } \\
\text { mental Management }\end{array}$ \\
\hline
\end{tabular}

\section{REFERENCES}

[1] D. Kar, P. Sur, S.K. Mandal, T. Saha and R.K. Kole, "Assessment of heavy metal pollution in surface water," Int. J. Environ. Sci. Tech., vol. 5(1), pp. 119-124, 2008.

[2] D.G. Smith, "Heavy metals in New Zealand Aquatic Environment: A Review," Water Quality Centre, Ministry of Works and Development". Wellington, New Zealand, 1986.

[3] K. Squibb, "Toxicity of Metals," System wide program in toxicity University of Maryland. 2002. Available at: http://aquaticpath.umd.edu-/toxnurse/metals.pdf [Accessed Feb. 2008].

[4] D.S. Panda, R.K. Behera, R.K. Sahu and S.N. Bandhopadhya, "Heavy metal Pollution in Chilika Lake, A tropical lagoon," Orissa, India. Available at: http://ces.iisc.ernet.in/ [Accessed October, 2007] 2002.

[5] K. Ljung, "Heavy metal discharge into Lake Victoria - A study of the Ugandan cities of Kampala, Jinja and Entebbe", MSc Thesis, Swedish University of Agricultural Sciences, 2001.

[6] FAO, 1991. FAO Fisheries Report. Report of the $3^{\text {rd }}$ session of the Working Party on Pollution and Fisheries - Accra, Ghana, 25-29 
November 1991. Available at: http://www.fao.org/docrep/008/t0666e/T0666E02.htm. [Accessed November, 2009].

[7] UNEP, 2002. African Environment Outlook: past, present and future. Available at: http://www.unep.org/dewa/Africa/publications/AEO-1/index.htm. [Accessed November, 2009].

[8] S.O. Wandiga and J.M. Onyari, "The concentration of heavy metals $\mathrm{Mn}, \mathrm{Fe}, \mathrm{Cu}, \mathrm{Zn}, \mathrm{Cd}$ and $\mathrm{Pb}$ insediments from Winam Gulf", Kenyan J. Sci., vol. 8, pp. 5-18, 1987.

[9] D.O. Ogoyi, C.J. Mwita, E.K. Nguu and P.M. Shiundu, "Determination of Heavy Metal Content in Water, Sediment and Microalgae from Lake Victoria, East Africa," Open Environ. Eng. J., vol. 4, pp.156-161, 2011

[10] P.B.O. Ochumba, "Periodic massive fiss jkills in the Kenyan part of Lake Victoria", Water Qual. Bull., vol. 112, pp.119-122, 1987.

[11] D.S. Kisamo, "Environmental hazards associated with heavy metals in Lake Victoria Basin(East Africa), Tanzania. Afr. Newslett. Occup. Health Saf., vol. 13, pp. 67-69, 2003.

[12] E. Nkuranga, "Heavy metal removal and accumulation by an Urban Natural wetland: The Nyabugogo Swamp, Rwanda." MSc Thesis, UNESCO-IHE Institute for Water Education, 2007.
[13] V. Nzeyimana, "Quantitative and qualitative assessment of groundwater in Nyagatare District", MSc. Thesis, National University of Rwanda, 2008.

[14] A.H. Dushimire, "Water Balance of Lake Muhazi, Rwanda", MSc. Thesis, National University of Rwanda, 2008.

[15] F. Nshimiyimana, "Heavy metal assessment in akagera trans boundary river", MSc. Thesis, National University of Rwanda, 2009.

[16] Y.J. Ma and C.Q. Liu, "Seasonal migration of redox boundary and its influence on water quality," In: lake lugu, yunnan, China. The State Key Lab. of Environ. Geochemistry, Institute of Geochemistry, Chinese Academic Science. Ninth Annual. V.M. Goldschmidt Conference. 1999.

[17] CCME (Canadian Council of Ministers of the Environment). (2004). Canadian Water Quality Guidelines. Available at: http://www.ec.gc.ca/ceqg-rcqe/English/Ceqg/Water/default.cfm [Accessed November, 2007]

[18] WHO (World Health Organization), "Guidelines for drinking-water quality", $3^{\text {rd }}$ ed. Incorporating first addendum. Available at: http://www.who.int/water_sanitation_health, 2004.

(c) Nhapi et al.; Licensee Bentham Open.

This is an open access article licensed under the terms of the Creative Commons Attribution Non-Commercial License (http://creativecommons.org/licenses/by-nc/3.0/g) which permits unrestricted, non-commercial use, distribution and reproduction in any medium, provided the work is properly cited. 